\title{
Article \\ The Potential of the Biodigester as a Useful Tool in Coffee Farms
}

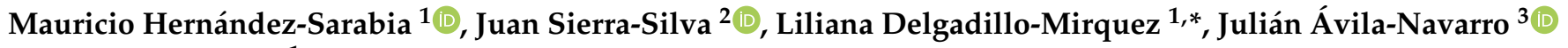 \\ and Laura Carranza ${ }^{1}$ \\ 1 Facultad de Ingeniería, Universidad de Ibagué, Ibague 730003, Colombia; \\ mauricio.hernandez@unibague.edu.co (M.H.-S.); laura.carranza@unibague.edu.co (L.C.) \\ 2 Proyecto de Cafés Especiales del Tolima, Universidad de Ibagué, Ibague 730003, Colombia; \\ juan.sierra@unibague.edu.co \\ 3 Dirección de Investigaciones, Universidad de Ibagué, Ibague 730003, Colombia; julian.avila@unibague.edu.co \\ * Correspondence: liliana.delgadillo@unibague.edu.co; Tel.: +57-320-3930677
}

Citation: Hernández-Sarabia, M.; Sierra-Silva, J.; Delgadillo-Mirquez, L.; Ávila-Navarro, J.; Carranza, L. The Potential of the Biodigester as a Useful Tool in Coffee Farms. Appl. Sci. 2021, 11, 6884. https://doi.org/ 10.3390/app11156884

Academic Editors: Ramaraj Boopathy and Alejandro Rodriguez Pascual

Received: 28 April 2021

Accepted: 23 July 2021

Published: 27 July 2021

Publisher's Note: MDPI stays neutral with regard to jurisdictional claims in published maps and institutional affiliations.

Copyright: (c) 2021 by the authors. Licensee MDPI, Basel, Switzerland. This article is an open access article distributed under the terms and conditions of the Creative Commons Attribution (CC BY) license (https:// creativecommons.org/licenses/by/ $4.0 /)$.

\begin{abstract}
Coffee is a highly productive agricultural product in the department of Tolima. The wet fermentation process of coffee generates about $80 \%$ of the waste, which is highly contaminated with organic matter that pollutes water sources, so anaerobic co-digestion techniques are implemented in coffee wastewater using Taiwan type biodigesters. According to the study of three biodigesters fed with coffee waste and animal manure, the aim is to show their potential application in coffee farms. These biodigesters generated a biogas production with $\mathrm{CH}_{4}$ concentrations between $49.1 \% \pm 4.6$ and $58.1 \% \pm 2.4$ in volume, in addition to the benefit of the biol used as fertilizer in the crops. The biogas produced can be used for cooking and can save around USD 40.17 in natural gas. Therefore, the biodigester is a potential tool to mitigate the harmful effects of coffee cultivation on the surrounding ecosystem and can project coffee production in a sustainable direction.
\end{abstract}

Keywords: anaerobic digestion; biogas; biol; coffee farming; material and energy balance; waste treatment

\section{Introduction}

Coffee production in Colombia during 2019 reached 14.8 million bags $(60 \mathrm{~kg} / \mathrm{bags})$, which was the fifth consecutive year of producing over 14 million bags. These statistics are due to the production of 21.4 bags per hectare, representing an exponential increase of $88 \%$ in 9 years. For the same year, the country had a total of 853,700 cultivated hectares of coffee, concentrated mostly in regions such as Tolima, Huila, Cauca, and Caldas [1]. Tolima is the country's third largest coffee producer, with a national contribution between 11 and $12.5 \%$ [2]. Out of a total of 47 municipalities in the Tolima regions, 38 are coffee growers, representing $29 \%$ of the department's main crops by area planted [2]. This activity brings to the economy more than 60,000 households that account for $68 \%$ of rural populations, in which $96 \%$ of farmers have coffee plantations of under 2 hectares [3]. This fact could complicate the treatment and disposal of waste and wastewater produced in coffee processing.

The traditional methodology used for coffee processing is wet fermentation (see Figure 1), in which the cherry pit (bean) is extracted from the pulp, then dried and prepared for export and roasting. The method is called the wet process because water is the primary means of both moving the coffee through the process and facilitating the extraction of the seed. This process is particularly important for the grower because it affects the aroma and flavor of coffee. Moreover, the wet process generates solid wastes and wastewater with a high content of organic matter [4]. The solid waste accounts for $60 \%$ of the fresh fruit and is composed of: pulp (67\%), mucilage (27\%), and husk (6\%), while wastewater is divided into two main forms: the pulping water with a high content of quickly fermenting sugar (honey water) and the wastewater generated from processing applications [5]. Thus, the characteristics of honey water from coffee processing are that 
it has an extremely low pH (4 to 4.5) and a Biochemical Oxygen Demand (BOD) of up to 20,000 mg/L as well as a Chemical Oxygen Demand (COD) of up to 50,000 mg/L, which make it difficult to treat by biological means [5]. These residues are often discharged into rivers or surrounding agricultural land without previous treatment because the farmer does not have the necessary knowledge or resources to protect the environment $[6,7]$.

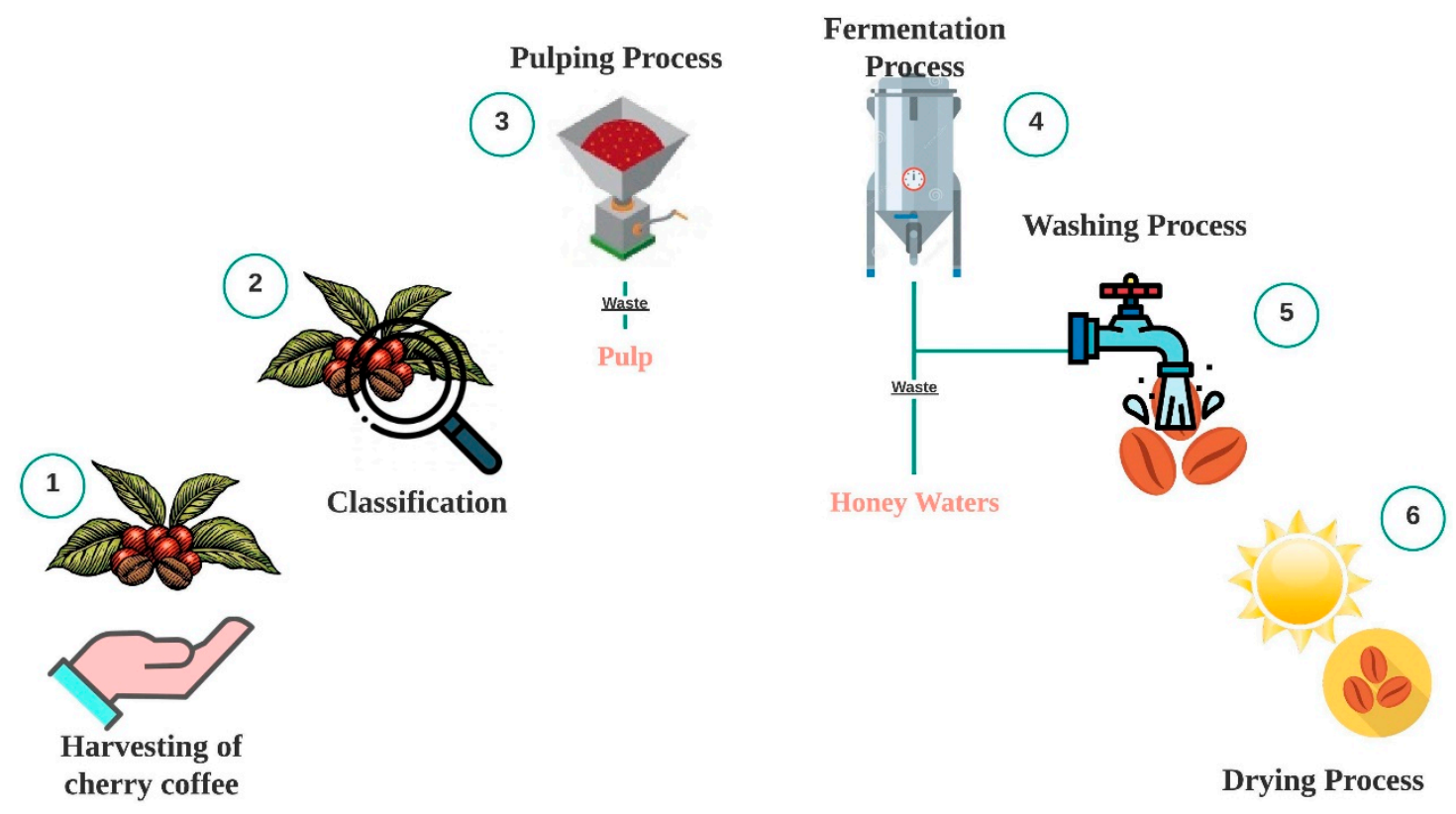

Figure 1. Stages of coffee harvesting process.

Dadi et al. [6] evaluated the impact of effluents from traditional wet coffee processing plants on the downstream water quality in Ethiopia. The organic content of the effluents was considerably high with values of $7200 \mathrm{mg} / \mathrm{L}$ and $871 \mathrm{mg} / \mathrm{L}$ for COD and BOD, respectively. This high pollution level caused a depletion of dissolved oxygen to levels of $0.25 \mathrm{mg} / \mathrm{L}$ in the effluents and the presence of nutrients invoked a large risk of eutrophication. As a result, the polluting potential of the wet coffee process from the coffee farm is enormous. Thus, to comply with the environmental regulations and achieve the restoration of the environment, it is necessary to find an economical and easily adaptable technology for the treatment of honey water.

Literature reviews indicate several treatment methods for coffee wastewater. These include physicochemical processes, such as adsorption, advanced oxidation, and biological processes such as the use of an up-flow anaerobic sludge blanket (UASB) reactor [8,9]. However, on a small-scale in rural areas, the treatment of wastewater from coffee processing requires a simple, efficient, and cost-effective system. Moreover, several authors have demonstrated that the anaerobic digestion of coffee wastewater could be an attractive solution in rural areas for the production of renewable energy in the form of biogas [10-12]. In this regard, Centro Nacional de Investigación del Café (CENICAFE) developed a Modular Anaerobic Treatment System (MATS) for coffee farms in the Colombian mountains [11]. This economical and environmentally friendly system is composed of two tanks where the anaerobic process is separated into hydrolysis-acidogenesis and methanogenesis stages. It has been established that this type of bioreactor is an excellent system for treating honey water with a high organic load, but its major drawback is that it does not remove the nutrients and the high content of the quickly fermenting matter in the effluent could cause a fast acidification of the wastewater resulting in an increase in VFA.

As an alternative, biodigesters are systems designed to optimize biogas production from agricultural wastes, manure, or industrial effluents. They are considered sustainable and appropriate for on-site wastewater treatment because of their simplicity, cost effectiveness, small footprint, low energy and nutrients demand, and fewer requirements of 
professional management. This study investigated the potential of three tubular biodigesters (Taiwan type) for honey water treatment in coffee farms. These digesters used substrates for co-digestion in which honey water was mixed with swine and cattle manure. Moreover, biodigesters are localized approximately between 1300 and 2000 m.a.s.l., with average room temperatures of $17^{\circ} \mathrm{C}$ to $30^{\circ} \mathrm{C}$ because good coffee can only grow at high altitudes. This is part of the "Cafés Especiales del Tolima" project, which seeks to improve post-harvest processes and transfer technologies for the appropriate management of wastewater. All of this is aimed at establishing a circular economy that will enable coffee growers to develop an agricultural, and an environmentally sustainable, activity.

\section{Materials and Methods}

\subsection{Preliminary Studies on the Status of the Use of Biodigesters in Coffee Farms}

Through the survey conducted as a part of this research project, which included a total of 551 coffee growers surveyed from thirteen prioritized municipalities in the department, it was found that approximately $5.0 \%$ of them had biodigesters installed on their farms. Thus, the management of solid and liquid waste had a contribution of $74.4 \%$ and $32.5 \%$, respectively. Of these, $31.5 \%$ of wastes were disposed of in water-courses, while $4.5 \%$ were buried, $0.9 \%$ were composted, and $1.0 \%$ were disposed of in septic tanks. However, $84.4 \%$ used a grease filter as a type of wastewater treatment. However, only $0.36 \%$ of those interviewed treated the coffee wastewater (honey water) generated in the process.

Taking into account the information gathered, the "Cafés Especiales del Tolima" project transferred Taiwan-type rural biodigesters to a group of coffee growers that were selected based on the criteria presented in the study conducted by Bermeo-Andrade, where coffee growers were classified according to their farmer profile and farm profile [13]. These digesters were used for the suitable processing of wastewater from the coffee process, the generation and use of biol as fertilizer, and the use of biogas in the drying of coffee.

\subsection{Substrate Characterization}

In this study, the feeding process for biogas production incorporated swine manure, cattle manure, and honey water. Food was provided as follows: $50 \%$ pig manure, 30\% cow manure, and $20 \%$ honey water, for substrate conformation. Subsequently, it was mixed with a 3 to 1 ratio, where 3 was water and 1 was substrate, i.e., $1 \mathrm{~L}$ of the feed mixture contained $750 \mathrm{~mL}$ of water and $250 \mathrm{~mL}$ of substrate. The conformation of the substrate mentioned above was obtained by laboratory experimentation.

Swine manure has a high nitrogen content and is a potential source of $\mathrm{CH}_{4}$ per unit of fresh matter [14]. Therefore, it was employed to avoid pollution estimated at $4.87 \mathrm{~kg}$ of $\mathrm{CO}_{2}$ equivalent per kg of carcass [15]. Bovine manure has been established as a suitable substrate for anaerobic digestion due to the ability of the microorganisms present to decompose other organic matter. The decomposition capacity depends on variables such as geographical location, feed sources, and age and species of the animals [16], so bovine manure is also considered as a potential source for biogas production by anaerobic digestion [17]. The result of manure treatment by this technology gives benefits such as reduction of ammonia and carbon dioxide emissions and reduction of greenhouse gas emissions. The energy valuation of cattle manure is approximately $0.04 \mathrm{~m}^{3} / \mathrm{kg}$ of biogas production [18].

Coffee's honey water is a subproduct from the coffee beneficiation process, composed of anaerobic microorganisms such as yeasts, mucilage bacteria, succinic acid, formic acid, butyric acid, aldehydes, ketones, and esters. These microorganisms are useful to increase the degradation of the substrate in the anaerobic process carried out in the biodigester [19]. Thus, honey water is a highly polluted substrate because the organic load decreases the amount of oxygen in the water, consequently leading to a deterioration of aquatic ecosystems [20]. Due to the previous, the necessity to use treatment processes for honey water is apparent. Table 1 shows a summary of data on the chemical properties of cattle manure, swine manure, and coffee's honey water from studies found in the scientific literature and measured by experimentation. 
Table 1. Chemical properties of swine manure, cattle manure, and coffee's honey waters.

\begin{tabular}{|c|c|c|c|c|c|c|}
\hline \multirow{2}{*}{ Characteristic } & \multicolumn{2}{|c|}{ Swine Manure } & \multicolumn{2}{|c|}{ Cattle Manure } & \multicolumn{2}{|c|}{ Coffee's Honey Waters } \\
\hline & Literature * $^{*}$ & Measured & Literature * & Measured & Literature * & Measured \\
\hline $\mathrm{pH}$ & $6.40-7.87$ & $7.6-8.2$ & $6.20-7.40$ & $7.2-7.5$ & $3.05-4.23$ & $3.8-4.0$ \\
\hline Total solids (\%) & $2.13-31.0$ & $17-23$ & $2.64-31.6$ & $12-33$ & - & - \\
\hline Volatile solids (\% TS) & $26.93-86.1$ & $70-82$ & $2.16-91.0$ & $69-84$ & - & - \\
\hline Total Carbon (\% TS) & $26.6-32.9$ & - & - & - & - & - \\
\hline $\mathrm{CH}_{4}$ production (\%) & $21.84-65.0$ & - & - & - & - & - \\
\hline $\mathrm{NH}_{4}^{+} \mathrm{N}(\mathrm{mg} / \mathrm{L})$ & $400-831$ & - & - & - & - & - \\
\hline TCOD $(\mathrm{g} / \mathrm{L})$ & - & - & $100.1-393$ & - & - & - \\
\hline $\mathrm{COD}(\mathrm{mg} / \mathrm{L})$ & - & $5.2-6.8 \times 10^{3}$ & - & - & $500-1.29 \times 10^{5}$ & $1.35-1.63 \times 10^{4}$ \\
\hline Total suspended solids (mg/L) & - & - & - & - & $52.6-14.75 \times 10^{3}$ & - \\
\hline Suspended solids (mg/L) & - & - & - & - & $940-19 \times 10^{3}$ & - \\
\hline Total nitrogen $(\mathrm{mg} / \mathrm{L})$ & - & - & - & - & 135 & $162-213$ \\
\hline Dissolved oxygen $(\mathrm{mg} / \mathrm{L})$ & - & - & - & - & 1.25 & - \\
\hline
\end{tabular}

*: Literature data taken from: [14,15,21-29].

Swine and cattle manure samples and coffee's honey water samples were analyzed for various physicochemical parameters, as Total Solids (TS), Volatile Solids (VS), and Chemical Oxygen Demand (COD), according to Standard Methods for the Examination of Water and Wastewater [30].

\subsection{Biodigester}

The main function of rural biodigesters is to capture methane $\left(\mathrm{CH}_{4}\right)$ emissions generated, by decomposition of organic matter from agriculture activities. In this way, it is possible to use this waste as an energy source and minimize the contribution of greenhouse gases in the environment [31]. The main components of the rural biodigester are observed in Figure 2.

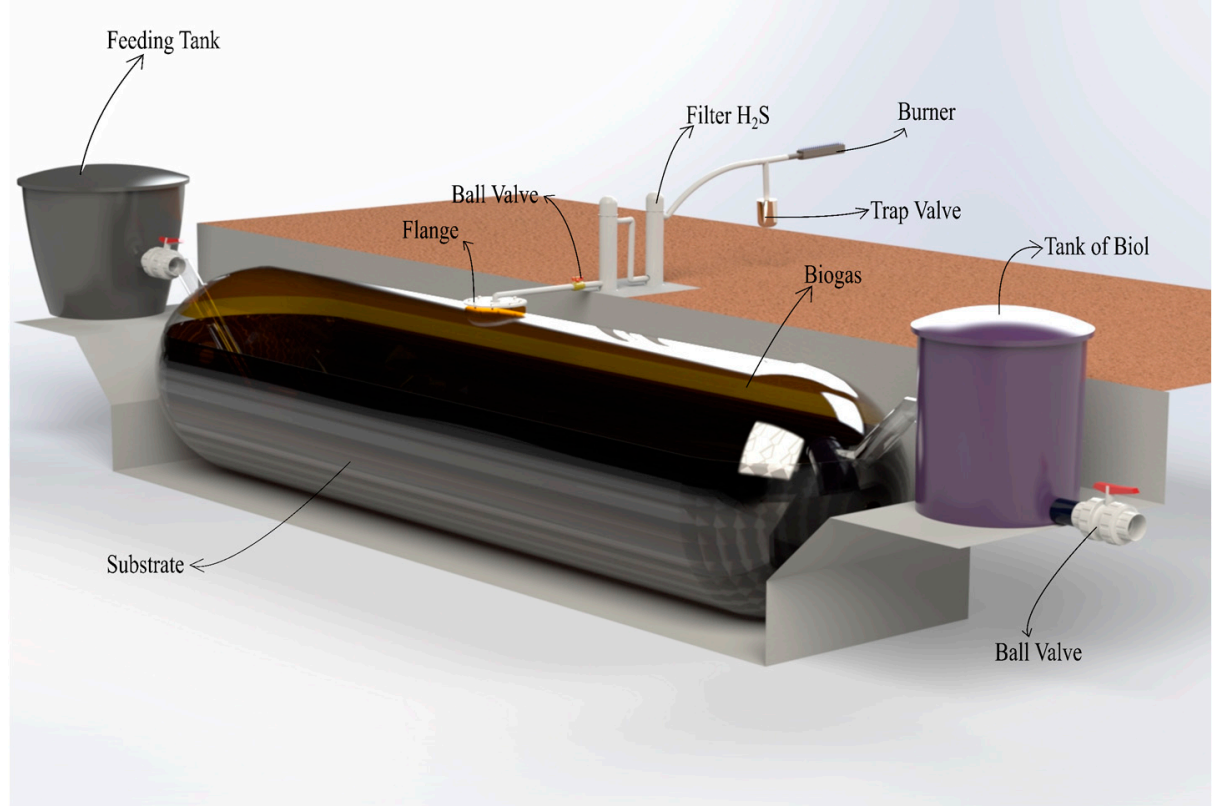

Figure 2. Stages of coffee harvesting process.

Farms that use waste, especially swine manure, have chosen the application of tubular or bag (Taiwan type) biodigesters. This type of biodigester is low cost, low design, and low maintenance. The Taiwan biodigester combines the digestion chamber, sedimentation tank, and gasometer in a single unit. The operation of this equipment is based on the plug-flow, where the substrate does not occupy the total volume because there is a space margin for the biogas [32]. Besides, these systems have been used as a method for the treatment of 
swine or bovine excreta in coffee farms during harvest periods, adding the residues of this activity, specifically honey water. Table 2 shows the physical and technical characteristics of the biodigesters installed in coffee farms.

Table 2. The physical and technical characteristics of Taiwan biodigesters installed.

\begin{tabular}{ccccccc}
\hline Material & Diameter $(\theta)$ & Length & T.V. ${ }^{*}$ & HRT & Outlet Valve & E.C. ${ }^{*}$ \\
\hline $\begin{array}{c}\text { PVC } 1005 \\
\text { geomembrane }\end{array}$ & $0.8 \mathrm{~m}$ & $8 \mathrm{~m}$ & $4 \mathrm{~m}^{3}$ & 35 days & $1 / 2^{\prime \prime}(12.7 \mathrm{~mm})$ PVC & $6.2 \mathrm{kw}$ \\
\hline$*$ T.V., Total Volume; E.C., Energy Capacity. & & & & &
\end{tabular}

\subsubsection{Biogas}

The biogas composition varies according to the type of feedstock and the operating conditions of the biodigester. It is estimated that biogas can be composed of approximately $50 \% \mathrm{CH}_{4}$ and $50 \% \mathrm{CO}_{2}$ or $75 \% \mathrm{CH}_{4}$ and $25 \% \mathrm{CO}_{2}$. However, traces of other components such as water vapor $\left(\mathrm{H}_{2} \mathrm{O}\right)$, hydrogen sulfide $\left(\mathrm{H}_{2} \mathrm{~S}\right)$, and ammonia $\left(\mathrm{NH}_{3}\right)$ may be present [33]. To measure the biogas concentration, the Multitec 540 gas measuring equipment from the company SEWERIN was used. This equipment allows the measurement in situ of $\mathrm{CH}_{4}$ $(0.0-100 \% \mathrm{Vol}), \mathrm{CO}_{2}(0-100 \% \mathrm{Vol}), \mathrm{CO}(0-500 \mathrm{ppm}), \mathrm{H}_{2} \mathrm{~S}(0-2000 \mathrm{ppm})$, and $\mathrm{O}_{2}(0-25.0 \% \mathrm{vol})$. The recorded data from biogas concentration measurements involved a statistical analysis focused on standard deviation to quantify the dispersion of the measurements.

\subsubsection{Hydrogen Sulfide Filter}

Figure 3 shows an illustration of the sulfuric acid filter used in the biodigester. The first stage of the filter (S1) has a filling of iron filings where the iron oxide reacts with the acid forming iron sulfide (III-Fe $\mathrm{S}_{2}$ ). In the second stage (S2) the adsorption process with activated carbon occurs. Thus, the filter installed purifies the biogas obtained, reducing the sulfuric acid content of the anaerobic digestion of the biodigesters installed in the coffee farms.

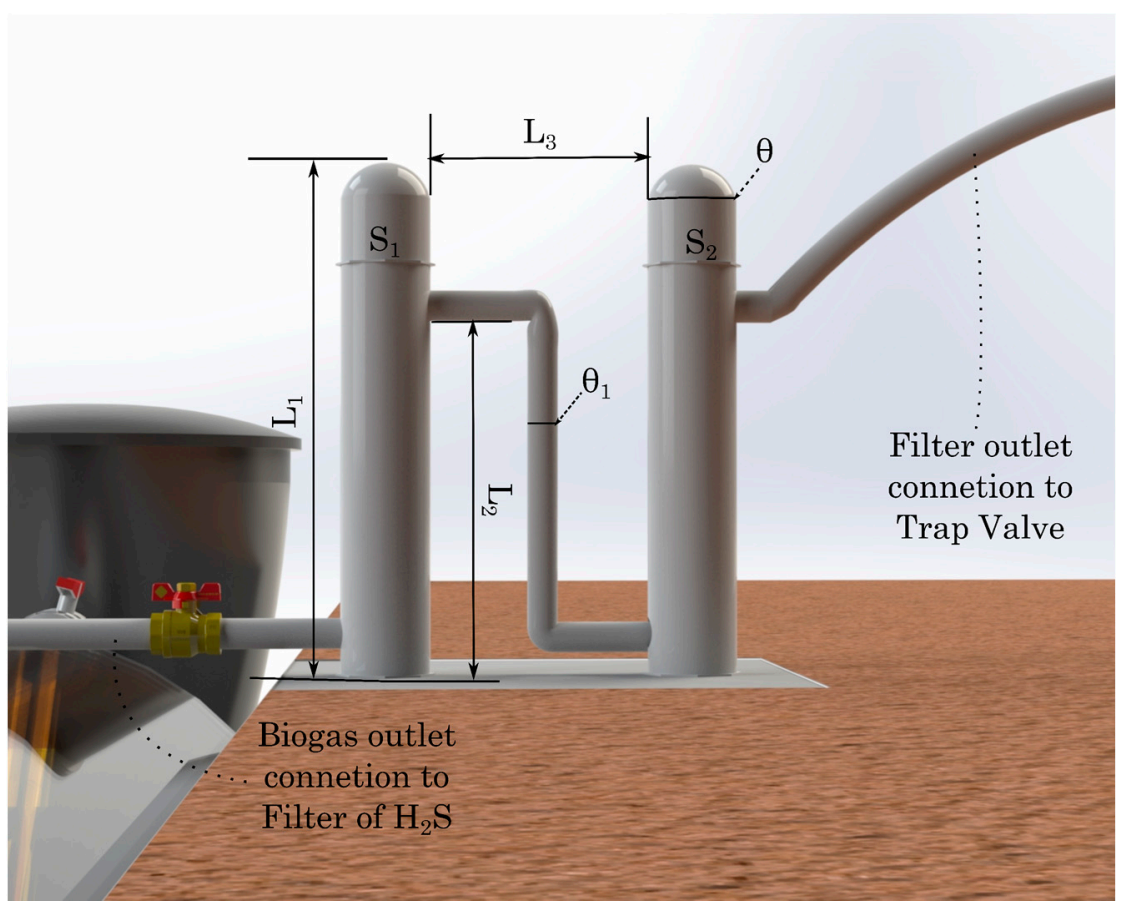

Figure 3. Hydrogen sulfide filter used at biodigester output.

\subsection{Aspects of Economic Analysis}

Based on cash flow, the net present value (NPV) Equation (1), internal rate of return (IRR), benefit-cost ratio (BCR), and payback period (PBP) criteria were used to evaluate the 
financial viability of investment in a biodigester at coffee farms. Net present value (NPV) is the difference between the present value of cash inflows and the present value of cash outflows over a period of time. In this study, $12.5 \%$ discount rate was chosen based on the interest rate charged by the bank and assumed 20 years of useful economic life of a biodigester when adequately maintained.

$$
N P V=-C_{0}+\sum_{t=1}^{T} \frac{R_{t}}{(1+i)^{t}}
$$

where $C_{0}$ is total investment cost, $R_{t}$ net cash during a single period $t, i$ is discount rate or return that could be in alternative investments and $t$ number of time periods. Under the NPV criterion, investments with positive NPV are considered to be economically feasible. The internal rate of return (IRR) is a discount rate that makes the net present value (NPV) of all cash flows equal to zero in a discounted cash flow analysis. The benefit-cost ratio (BCR) is a ratio between the relative costs and benefits of the biodigester proposed; if a $\mathrm{BCR}$ is greater than 1.0, the project is expected to deliver. The PBP refers to the number of years it would take for an investment to return the original costs through the annual net cash revenue it generates.

\section{Results and Discussion}

\subsection{Biogas Concentration}

Table 3 shows the data recorded in the technical visits carried out in the study municipalities. These data are related to the concentration of biogas in different coffee farms with their corresponding altitude. The coffee farms shown in Table 3 were selected according to the criteria shown by Bermeo [13].

Table 3. Biogas concentration data from three farms selected from the project.

\begin{tabular}{cccccc}
\hline Municipality & Farm & $\begin{array}{c}\text { Altitude } \\
\text { (m.a.s.1.) }\end{array}$ & $\mathbf{C H}_{\mathbf{4}}$ (Vol. \%) & $\mathbf{C O}_{\mathbf{2}}$ (Vol. \%) & $\mathbf{H}_{\mathbf{2}} \mathbf{S}(\mathbf{p p m})$ \\
\hline Chaparral & El Mirador & 1710 & $49.1 \pm 4.6$ & $43.0 \pm 3.9$ & $68.0 \pm 6.0$ \\
Chaparral & El Desierto & 1525 & $58.1 \pm 2.4$ & $27.0 \pm 2.8$ & $35.0 \pm 1.4$ \\
Planadas & El Tesoro & 1500 & $55.8 \pm 2.9$ & $44.2 \pm 2.6$ & $53.2 \pm 4.3$ \\
\hline
\end{tabular}

The concentrations obtained agree with those reported by different authors [14,34-36] for this type of biodigester and fed with pig manure where the altitudes are lower than those reported in this research. Therefore, this indicates that the co-digestion of pig manure, cow manure, and honey water substrates presents an adequate behavior for the generation of biogas. Thus, the amount of energy produced is sufficient for domestic use in food cooking, replacing the use of firewood and Liquefied Propane Gas (LPG) in the coffee farms of the region. Additionally, a methane concentration higher than $50 \%$ is an indication of a good conversion of organic matter to methane in the anaerobic digestion process, taking into account that in these evaluated systems there are changes in the organic feed load due to the operating conditions of the farms $[37,38]$.

\subsection{Energetic Application}

The biogas generated by the liquid manure from pigs contains $65 \%$ of $\mathrm{CH}_{4}$ approximately; therefore, it is estimated that one cubic meter of this gas can have an energy content of $9.97 \mathrm{kWh}$ and, thus, the energy contained in the biogas is $5.56 \mathrm{kWh} / \mathrm{m}^{3}$ [31]. Considering the above, the biogas production can be used as a supply system for different energy devices such as: a flute burner, heat exchanger, fan, solar tunnel dryer (canopy), and diffuser. Figure 4 shows the external elements of the biodigester for the energetic application of the biogas produced. 


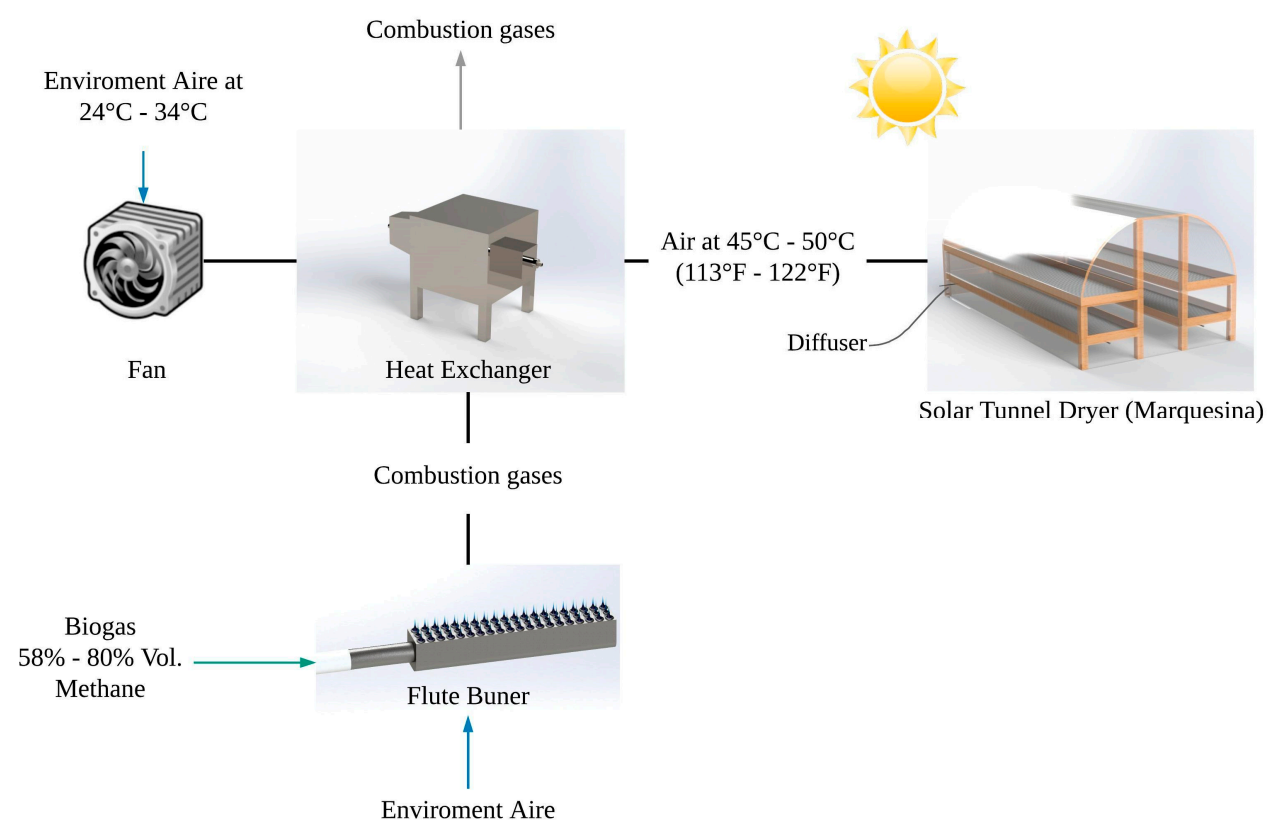

Figure 4. Scheme of energetic applications involved in thermal systems.

The flute burner is a device used for biogas combustion. In Paulauskas' study, it was observed that methane concentrations between $58.0 \%$ and $80.0 \%$ presented a high flame intensity in plasma measurements at $3 \mathrm{kHz}$ and $10 \mathrm{kHz}$ [39]. The gases produced by the combustion of the biogas are transferred to the heat exchanger through one of the inputs to heat the air driven by a fan. The heat exchanger is designed with a high heat transfer coefficient to transfer heat from one fluid to another [40]. For this study, it was a cross-flow heat exchanger, in that the fluid to be heated (air) passes through a series of tubes while the hot fluid passes through the shells (flue gases).

\subsection{Biogas Assisted Coffee Drying Process}

Two by-products of anaerobic digestion of coffee waste are expected: (1) Biogas for cooking and other energy uses and (2) Biol as soil remediation. In the same way, the co-digestion used, given by the combination of substrates, allows an appropriate $\mathrm{pH}$ adjustment at the process input, and a nutrient balance that favors the microorganism growing. The innovation of the project focuses on the use of biogas for coffee drying, which is carried out in parabolic solar dryers (marquesinas) assisted by hot air flow $\left(40-45^{\circ} \mathrm{C}\right)$. The internal temperature of the dryer should not be higher than $45^{\circ} \mathrm{C}$, to avoid losses in the organoleptic characteristics of the coffee. The thermal energy of the biogas raises the temperature of the air flow that passes through a heat exchanger before reaching the dryer. In the biodigesters studied, approximately $19 \mathrm{~m}^{3}$ of biogas per day is expected, producing $548 \mathrm{~kg}$ of dry coffee with a humidity of $12.5 \%$. The thermal system designed allows the coffee grower greater control over the drying of the coffee, guaranteeing the necessary temperatures for the process. Here, solar energy and thermal energy provided by biogas are combined, reducing the time required for drying.

\subsection{Operational Analysis of the Biodigester}

The analyses of specimens taken at the entrance of the biodigester present on average a value of $8.04 \pm 1.03 \%$ (Total Solids) TS and a value of $76.57 \pm 2.39$ for the ratio percentage VS/TS (Volatile Solids/Total Solids). In agreement with Saavedra [32], the value of percentage TS in the mixture manure-water must be around $8 \%$ so that the model of the biodigester type piston-flow does not have agitation. Higher values infer an accumulation of solids, a decrease in Hydraulic Retention Time (HRT), and low biogas production. By the parameters of the environment where biodigesters are located (temperature), these must have 35 to 45 days HRT [34]. However, the variation in the number of animals 
in the pens influences the HRT parameter, in this case this is longer than that proposed by Martí-Herrero.

Conversely, the organic load parameter of the specimens does not establish a specific composition to characterize each biodigester. The above was due to the type, amount, age, size, sale, and purchase of livestock (swine and cattle), although a range of 20 to 30 adult animals was established on the visited farms. Based on Martí-Herrero and Saavedra's studies [32,34], a pig of $100 \mathrm{~kg}$ provides $4 \mathrm{~kg}$ of manure dairy. In addition, $1 \mathrm{~kg}$ of fresh manure generates $51 \mathrm{~L}$ of biogas (depending on HRT and temperature); $1 \mathrm{~m}^{3}$ of biogas equates to using $1.3 \mathrm{~kg}$ of wood, approximately. Hence, to take an average of 25 pigs, each one with an average weight of $68 \mathrm{~kg}$, could produce $3.45 \mathrm{~m}^{3}$ of biogas (i.e., $4.5 \mathrm{~kg}$ of wood).

The analysis of $\mathrm{pH}$ for each one of the materials of biodigesters inspected at the entrance and exit were similar, these oscillating between 6.9 to 7.5 , inferring that there was a stable anaerobic process. In terms of the Carbon/Nitrogen ratio $(\mathrm{C} / \mathrm{N})$, this is considered optime in the 20 to 30 range for anaerobic digestion [41]. The literature describes that co-digestion of manure and other substrates can overcome the low damping capacity of the substrate and the accumulation of Volatile Fatty Acids in that process due to the established $\mathrm{pH}$ range of methanogenesis in conjunction with its high inherent capacity of damping. When the ratio is low $(\mathrm{C} / \mathrm{N}=10)$ it follows that there are losses of assimilable nitrogen against, a high ratio $(\mathrm{C} / \mathrm{N}=40)$ inhibits the growth of microorganisms for lack of nitrogen. In this sense, it has been reported that coffee's honey waters have a ratio $\mathrm{C} / \mathrm{N}$ of 15.63 , stating that there is a proportion of nutrients with a high content of nitrogen [42]. In contrast, swine manure can have a variable ratio of $\mathrm{C} / \mathrm{N}$, between 17 and 22 [41]. Therefore, the co-digestion of swine manure and coffee's honey waters can be in the lower range, distinctive by the losses of nitrogen.

\subsection{Biogas Concentration and Biol}

The variations in the methane concentration obtained in the measurements were between $49.1 \% \pm 4.6 \mathrm{vol}$. and $58.1 \% \pm 2.4$ vol., and the sulfur dioxide concentration presented a range of values between 24 and 31\% vol. Likewise, in the cleaning process of biogas to eliminate water dread and $\mathrm{H}_{2} \mathrm{~S}$ with the help of the sulfuric acid filter (iron straps), a range between 0.20 and $0.25 \%$ vol. was obtained. These measurements were accomplished with measures established by FAO [43] for the composition of biogas from swine manure. Meanwhile, the analysis of biogas in terms of $\mathrm{H}_{2} \mathrm{~S}$ before and after the cleaning process in the filter, exhibited a low or null removal. Therefore, this suggests that there was a lack of periodic maintenance to filter as well as a lack of the implementation of new technologies to eliminate the corrosive and toxic gas of biogas.

Once the co-digestion process was completed in the biodigester, a substance (biol, a mixture of liquids and solids) was produced that could be used as organic fertilizer for different crops such as coffee, corn, sugar cane, and fruit trees on the farms visited. The above is supported under the agricultural application standards of the Colombian regulations on organic products (Colombian Technical Standard-(NTC) 5167 and Decree No. 1287 of 2014, on the Use of Digestate in Agriculture) [44,45]. The physicochemical characteristics of Biol act as a nutrient regulator in plant growth. In essence, Biol has a content of 2 to $3 \%$ nitrogen, 1 to $2 \%$ phosphorus, potassium around 1 to $85 \%$ of organic matter with neutral $\mathrm{pH}$ [34]. Additionally, the use of Biol has considerably decreased the application of commercial fertilizers, thus representing a soil conservation alternative and a decrease in the cost of production, [46-48]. Hence, the number of farms visited with this characteristic was higher than before, giving the coffee grower an additional value to his harvest and product (organic coffee).

\subsection{Economic Analysis}

The implemented study provides an approach to the economic analysis of the biodigester on the coffee farms studied. We analyzed different economic indicators taking into account the investment, costs, and benefits of the application of biodigester on farms. The 
major cost components of the biodigester included the investment cost incurred to acquire the digester, and the operational and maintenance costs. The key part of the operational cost is the household labor time on various activities such as collecting substrate, mixing feedstock, and feeding the digester. The benefits gained include biogas for cooking, use of biol as a fertilizer, improvement in health, and reduction in negative environmental impacts. Nevertheless, sometimes social and environmental benefits are difficult to quantify (not measured). Biogas benefits are due to: (1) the substitution of fuelwood and LPG for biogas, (2) reduction in labor for fuelwood collection, and (3) the cost of LPG saved.

On average the investment of the biodigester was approximately USD 1424, which included a flexible balloon, pipe connections, biogas filter, tanks for feeding and leaving the substrate, stove, transportation and installation, labor cost, civil work, and protection cover. The operational costs were obtained by asking the farmers how much time they spent on carrying out the activities each time they fed the digester. As a result, the time operational was estimated at $1 / 5$, which would translate into a price of one fifth of the current legal minimum wage. However, it is possible that the costs associated with the labor for fuelwood collection are offset by the biodigester activities.

The benefits were mainly divided into two: savings in the LPG cost and saving in fertilizer consumption. According to the information collected, each household consumed at least one LPG cylinder per month. This is the cost saved by using biogas for cooking. Regarding the replacement of fertilizer by biol, a saving of one third is expected. On average, a coffee farm uses 35 bags of fertilizer per hectare annually. So, for a two-hectare farm, USD 2554 per year would be paid. This could translate into savings of USD 851 annually for the first year.

Table 4 shows the cash flow for a period of five years with a fixed annual variation of $3.5 \%$ (corresponds to an average annual inflation). Equipment depreciation and maintenance costs are included, which corresponds to $2 \%$ of the investment.

Table 4. Cash flow form biodigester application on coffee farm (USD/year).

\begin{tabular}{|c|c|c|c|c|c|c|}
\hline & \multicolumn{6}{|c|}{ Year } \\
\hline & 0 & 1 & 2 & 3 & 4 & 5 \\
\hline (+) Savings form LPG & - & 226 & 234 & 242 & 250 & 259 \\
\hline (+) Savings form fertilizer & - & 851 & 881 & 912 & 944 & 977 \\
\hline$(-)$ Operational cost & - & 586 & 607 & 629 & 650 & 672 \\
\hline$(-)$ Maintenance cost & - & 28 & 29 & 30 & 31 & 32 \\
\hline$(-)$ Equipment depreciation & - & 21 & 21 & 21 & 21 & 21 \\
\hline$(=)$ Net cash & - & 442 & 458 & 475 & 492 & 511 \\
\hline$(+)$ Depreciation & - & 21 & 21 & 21 & 21 & 21 \\
\hline$(+)$ Investment & -1.424 & - & - & - & - & - \\
\hline Cash flow & -1.424 & 463 & 479 & 496 & 513 & 532 \\
\hline
\end{tabular}

In this analysis, a $12.5 \%$ discount rate was chosen based on the average interest rate charged by a bank in Colombia. As a result of cash flow, NPV was positive and IRR (21\%) was higher than the discount rate. The positive response is attributed to taking into account the use of biogas and biol for farm activities. Therefore, BCR is greater than 1.0 and PBP was estimated at 3.9 years. In contrast, Kabyanga estimated a negative NPV and PBP of 5.2 years for biodigester implementation in Africa, attributed mainly to the high investment cost of the technology [49]. According to Ash Shiddiq, the design of a biodigester to fulfill cooking gas sourced from one cow's manure is optimal and profitable in Indonesia, [50]. This produces $2.247 \mathrm{~m}^{3}$ gas / day and results in a positive NPV, 32.3\% of IRR, 2.7 years of PBP, and 1.78 times of BCR based on price and cost reference.

Moreover, we simulated a scenario without using the biol as fertilizer, and the results showed a negative NPV and IRR, BCR minor to 1.0, and PBP of 12.5 years. Although the PBP was less than the useful life of the biodigester (20 years), in this scenario the technology loses viability, and it would be necessary to adopt government incentives to encourage 
the use of biogas from anaerobic wastewater treatment. As a result, fertilizer prices are important in terms of economic feasibility and biol uses can be more important than the biogas in the condition under this study.

\section{Conclusions}

The anaerobic digestion process was proven to be an application useful for the care, growth, and obtaining of a product that is eco-sustainable on coffee farms. Additionally, by its nature, renewable biogas allows for the replacing of fuels such as firewood in a way that is more efficient and, likewise, to make the use of a biodigester for the treatment of honey waters more attractive. The use of biogas would also replace the propane gas usually employed. The composition of the biogas analyzed allows the delivery of sufficient energy for cooking and drying coffee in the on-farm process.

The studies and analyzes performed regarding the co-digestion process in the biodigesters installed determined a reliance on substrates because these help to maintain stable conditions and avoid affecting the microbial diversity in charge of the transformation of matter to biogas. Consequently, it is considered important for the maintenance and engagement of farmers to achieve efficiency of the system. Due to this, the environment conditions can severely affect the physical condition of components (heat exchanger, solar tunnel dryer, biogas pipeline and biodigester) because these are submerged natural habitats. The proposed thermal system allows for the drying of coffee through the use of biogas, reducing process times and maintaining appropriate temperatures.

On the other hand, biol has been considered as a beneficial subproduct, on account of its properties, as a natural fertilizer for the crops according to the literature studied. In addition, economic analysis infers that biol reduces the payback time due to savings in chemical fertilizer costs. However, the composition of biol and its effects on the soil require further study for coffee farms.

Therefore, the cost analysis shows that the investment will only be profitable in the fourth year and that the investment cost of the bioreactor is quite high compared to the benefits. This is due to the high cost of the technology, and, mainly, transport costs. This fact may require government incentives to improve social and environmental conditions in the rural sector. Consequently, the thermal system proposed in this research highlights the use of biodigesters as a useful tool in rural coffee growing areas because of its environmental impact mitigation of the coffee post-harvesting process and the economic sustainability of agriculture.

Future research should analyze the co-digestion process in coffee's honey waters, to comprehend the microbial dynamics and the stability of the anaerobic process. In addition, future research should evaluate the application to find an optimal dosage of biol and obtain a system that is more efficient in the soil to obtain eco-sustainable production.

Author Contributions: The authors are responsible for all the aspects of the manuscript. All authors have read and agreed to the published version of the manuscript.

Funding: This research has been financed by the project "Innovación de procesos a nivel de poscosecha para la incorporación de valor agregado en la diferenciación de cafés especiales del Tolima". Special cooperation agreement $\mathrm{N}^{\circ} 1874-2018$.

Institutional Review Board Statement: Not applicable.

Informed Consent Statement: Not applicable.

Data Availability Statement: All data are available after reasonable request to the corresponding author.

Acknowledgments: The authors appreciate the support of Gobernación del Tolima, in the financing of the project code BPIN 2016000100049, Innovación de procesos a nivel de poscosecha para la incorporación de valor agregado en la diferenciación de cafés especiales del Tolima, special cooperation agreement $\mathrm{N}^{\circ} 1874-2018$. In the same manner to the Universidad de Ibague by the financial support, technique, and administration of project code 18-487-ESP. Finally, to Cortolima for the support given in the visits made to the coffee farms in the department of Tolima. 
Conflicts of Interest: The authors declare that they have no conflict of interest.

\section{References}

1. Federación Nacional de Cafeteros de Colombia Informe de Gestión 2019. Available online: https://cdn.flipsnack.com/widget/ v2/widget.html?hash=dpazs597t9 (accessed on 23 July 2021).

2. MinAgricultura Colombia; Federación Nacional de Cafeteros. Área Sembrada y Área Cosechada del Cultivo de Producción y Rendimiento del Cultivo de Café 2007-2017. Available online: https:/ /www.agronet.gov.co/Documents/1-CAF\%C3\%89_2017 .pdf (accessed on 23 July 2021).

3. Federación Nacional de Cafeteros de Colombia Estadísticas Cafeteras. Available online: https://federaciondecafeteros.org/wp/ estadisticas-cafeteras/ (accessed on 23 July 2021).

4. Romero Loaiza, R.; Mamani Paro, R. Obtención de biogás como fuente de energía renovable a partir de los subproductos del café. Rev. Investig. Altoandinas 2013, 15, 241-252. [CrossRef]

5. Rattan, S.; Parande, A.K.; Nagaraju, V.D.; Ghiwari, G.K. A comprehensive review on utilization of wastewater from coffee processing. Environ. Sci. Pollut. Res. 2015, 22, 6461-6472. [CrossRef]

6. Dadi, D.; Mengistie, E.; Terefe, G.; Getahun, T.; Haddis, A.; Birke, W.; Beyene, A.; Luis, P.; Van der Bruggen, B. Assessment of the effluent quality of wet coffee processing wastewater and its influence on downstream water quality. Ecohydrol. Hydrobiol. 2018, 18, 201-211. [CrossRef]

7. Chinappi Ciccolella, I.; Jerez Carrizo, A. Biodigestión anaeróbica de la pulpa de café. Propuesta de saneamiento ambiental y ahorro energético. Rev. Acad. 2008, 13, 75-83.

8. Ijanu, E.M.; Kamaruddin, M.A.; Norashiddin, F.A. Coffee processing wastewater treatment: A critical review on current treatment technologies with a proposed alternative. Appl. Water Sci. 2019, 10, 1-11. [CrossRef]

9. Sengupta, B.; Priyadarshinee, R.; Roy, A.; Banerjee, A.; Malaviya, A.; Singha, S.; Mandal, T.; Kumar, A. Toward sustainable and eco-friendly production of coffee: Abatement of wastewater and evaluation of its potential valorization. Clean Technol. Environ. Policy 2020, 22, 995-1014. [CrossRef]

10. Corro, G.; Pal, U.; Bañuelos, F.; Rosas, M. Generation of biogas from coffee-pulp and cow-dung co-digestion: Infrared studies of postcombustion emissions. Energy Convers. Manag. 2013, 74, 471-481. [CrossRef]

11. Zambrano, D.; Rodríguez, N.; López, U.; Orozco, P.; Zambrano, A. Tratamiento Anaerobio de las Aguas Mieles del Café; CENICAFÉ: Chinchiná, Colombia, 2006.

12. Rodríguez, S.; Pérez, R.; Boizán, M. Estudio de la biodegradabilidad anaerobia de las aguas residuales del beneficio húmedo del café. Interciencia 2000, 25, 386-390.

13. Bermeo-Andrade, H.; Bahamón-Monje, A.F.; Aragón-Calderón, R.; Beltrán-Vargas, Y.; Gutiérrez-Guzmán, N. Is coffee (Coffea arabica 1.) quality related to a combined farmer-farm profile? Sustainability 2020, 12, 9518. [CrossRef]

14. Chen, C.; Zheng, D.; Liu, G.J.; Deng, L.W.; Long, Y.; Fan, Z.H. Continuous dry fermentation of swine manure for biogas production. Waste Manag. 2015, 38, 436-442. [CrossRef]

15. Wijesinghe, D.T.N.; Suter, H.C.; Scales, P.J.; Chen, D. Lignite addition during anaerobic digestion of ammonium rich swine manure enhances biogas production. J. Environ. Chem. Eng. 2021, 9, 104669. [CrossRef]

16. Manyi-Loh, C.; Mamphweli, S.; Meyer, E.; Okoh, A. Characterizing bacteria and methanogens in a balloon-type digester fed with dairy cattle manure for anaerobic mono-digestion. Polish J. Environ. Stud. 2019, 28, 1287-1293. [CrossRef]

17. Franco, R.T.; Buffière, P.; Bayard, R. Cattle manure for biogas production. Does ensiling and wheat straw addition enhance preservation of biomass and methane potential? Biofuels 2017, 11, 671-682. [CrossRef]

18. López Martínez, G.; Buriticá Arboleda, C.; Silva Lora, E. La biomasa residual pecuaria como recurso energético en Colombia. Visión Electron. 2018, 12, 180-188. [CrossRef]

19. Acarley, F.; Quipuzco, L. Producción de metano mediante digestión anaerobia de aguamiel, subproducto del beneficio húmedo del café. Agroind. Sci. 2020, 10, 7-16. [CrossRef]

20. Fluker Puscan, R.S.; Meléndez Mori, J.B.; Leiva Tafur, D.; Chávez Ortiz, J.; Rascón, J. Impacto del vertimiento de aguas mieles sobre la quebrada El Mito en el caserío El Mito, Distrito San Nicolás (Rodríguez de Mendoza-Amazonas). Rev. Investig. Agroproducción Sustentable 2018, 2, 57. [CrossRef]

21. Los Barbosa, F.J.; Cabral, A.R.; Capanema, M.A.; Schirmer, W.N. Biogas generation potential of anaerobic co-digestion of municipal solid wastes and livestock manures. J. Solid Waste Technol. Manag. 2018, 44, 248-258. [CrossRef]

22. Im, S.; Petersen, S.O.; Lee, D.; Kim, D.H. Effects of storage temperature on CH4 emissions from cattle manure and subsequent biogas production potential. Waste Manag. 2020, 101, 35-43. [CrossRef]

23. Abbas, Y.; Jamil, F.; Rafiq, S.; Ghauri, M.; Khurram, M.S.; Aslam, M.; Bokhari, A.; Faisal, A.; Rashid, U.; Yun, S.; et al. Valorization of solid waste biomass by inoculation for the enhanced yield of biogas. Clean Technol. Environ. Policy 2020, 22, 513-522. [CrossRef]

24. Budiyono, B.; Widiasa, I.N.; Johari, S.; Sunarso, S. Increasing Biogas Production Rate from Cattle Manure Using Rumen Fluid as Inoculums. Int. J. Sci. Eng. 2014, 6, 31-38. [CrossRef]

25. Gutiérrez Guzmán, N.; Valencia Granada, E.; Aragon Calderon, R.A. Eficiencia de Remoción en Sistemas de Tratamiento de Aguas Residuales del Beneficio de Café (Coffea arabica). Colomb. For. 2014, 17, 151. [CrossRef] 
26. Cárdenas Garzón, R.C.; Ortíz Prieto, J.E. Manejo Integrado del Recurso Agua en el Beneficio Húmedo del Café, para la Asociación de Productores de Café "Acafeto" en el Municipio de Fresno, Departamento del Tolima. Available online: https: / / ridum.umanizales.edu.co/xmlui/handle/20.500.12746/1265 (accessed on 23 July 2021).

27. Torres-Valenzuela, L.S.; Sanín-Villarrea, A.; Arango-Ramírez, A.; Serna-Jiménez, J.A. Caracterización fisicoquímica y microbiológica de aguas mieles del beneficio del café. Rev. ION 2019, 32, 59-66. [CrossRef]

28. Valencia, N.; Castañeda, S.; Osorio, A.; Quintero, L. Dispositivos para el Óptimo Funcionamiento Hidráulico de los Sistemas Modulares de Tratamiento Anaerobio (SMTA); Comité Edi.; Cenicafé: Manizales, Colombia, 2019.

29. Kafle, G.K.; Chen, L. Comparison on batch anaerobic digestion of five different livestock manures and prediction of biochemical methane potential (BMP) using different statistical models. Waste Manag. 2016, 48, 492-502. [CrossRef]

30. Rice, E.W.; Baird, R.B.; Eaton, A.D. Standard Methods for the Examination of Water and Wastewater, 23rd ed.; American Public Health Association, American Water Works Association, Water Environment Federation: Washington, DC, USA, 2017; ISBN 9780875532875.

31. Pérez-Espejo, R.; Cervantes-Hernández, G. Estrategias de mitigación. El programa de biodigestores en Yucatán, México. Península 2018, 13, 235-262.

32. Saavedra, R.; Alamo, M.; Marcelo, M. Diseño de un Biodigestor Tubular para Zonas Rurales de la Región Piura. In Proceedings of the XXIV Simposio Peruano de Energía Solar y del Ambiente (XXIV-SPES), Huaraz, Peru, 13-17 November 2017.

33. Ramirez-Perez, J.C. A Comparison of Performance between Two Anaerobic Biodigesters Configurations for Biogas Production. Rev. Técnica Energía 2018, 13, 213-223.

34. Martí-Herrero, J. Biodigestores Familiares: Guía de Diseño y Manual de Instalación; Cooperación Tecnica Alemana GZT: La Paz, Bolivia, 2008; Volume 53, ISBN 978-99954-0-339-3.

35. Battista, F.; Fino, D.; Mancini, G. Optimization of biogas production from coffee production waste. Bioresour. Technol. 2016, 200, 884-890. [CrossRef] [PubMed]

36. Widjaja, T.; Nurkhamidah, S.; Altway, A.; Iswanto, T.; Gusdyarto, B.; Ilham, F.F. Performance of biogas production from coffee pulp waste using semi-continuous anaerobic reactor. IOP Conf. Ser. Mater. Sci. Eng. 2019, 673, 012003. [CrossRef]

37. Laperrière, W.; Barry, B.; Torrijos, M.; Pechiné, B.; Bernet, N.; Steyer, J.P. Optimal conditions for flexible methane production in a demand-based operation of biogas plants. Bioresour. Technol. 2017, 245, 698-705. [CrossRef] [PubMed]

38. Nsair, A.; Cinar, S.O.; Alassali, A.; Qdais, H.A.; Kuchta, K. Operational Parameters of Biogas Plants: A Review and Evaluation Study. Energies 2020, 13, 3761. [CrossRef]

39. Paulauskas, R.; Martuzevičius, D.; Patel, R.B.; Pelders, J.E.H.; Nijdam, S.; Dam, N.J.; Tichonovas, M.; Striūgas, N.; Zakarauskas, K. Biogas combustion with various oxidizers in a nanosecond DBD microplasma burner. Exp. Therm. Fluid Sci. 2020, 118. [CrossRef]

40. Zainol, N.I.; Osaka, Y.; Tsujiguchi, T.; Kumita, M.; Kodama, A. Separation and enrichment of CH 4 and CO 2 from a dry biogas using a thermally regenerative adsorbent-packed heat exchanger. Adsorpt. J. Int. Adsorpt. Soc. 2019, 25, 1159-1167. [CrossRef]

41. Wang, X.; Yang, G.; Feng, Y.; Ren, G.; Han, X. Optimizing feeding composition and carbon-nitrogen ratios for improved methane yield during anaerobic co-digestion of dairy, chicken manure and wheat straw. Bioresour. Technol. 2012, 120, 78-83. [CrossRef] [PubMed]

42. Acarley, F. Evaluación de la Producción de Metano a Partir de las Aguas Mieles del Beneficio Húmedo del Café Mediante Digestión Anaerobia; Universidad Nacional Agraria la Molina: Lima, Perú, 2018.

43. Marchaim, U. Biogas Processes for Sustainable Development; Food and Agriculture Organization of the United Nations: Qiryat Shemona, Israel, 1992; ISBN 92-5-103126-6.

44. Instituto Colombiano de Normas Técnicas y Certificación [ICONTEC] Norma Técnica Colombiana [NTC] 5167. Available online: https://tienda.icontec.org/gp-productos-para-la-industria-agricola-productos-organicos-usados-como-abonos-ofertilizantes-y-enmiendas-o-acondicionadores-de-suelo-ntc5167-2011.html (accessed on 21 July 2021).

45. Parra-Orobio, B.A.; Rotavisky-Sinisterra, M.P.; Pérez-Vidal, A.; Marmolejo-Rebellón, L.F.; Torres-Lozada, P. Physicochemical, microbiological characterization and phytotoxicity of digestates produced on single-stage and two-stage anaerobic digestion of food waste. Sustain. Environ. Res. 2021, 31. [CrossRef]

46. Alfa, M.I.; Adie, D.B.; Igboro, S.B.; Oranusi, U.S.; Dahunsi, S.O.; Akali, D.M. Assessment of biofertilizer quality and health implications of anaerobic digestion effluent of cow dung and chicken droppings. Renew. Energy 2014, 63, 681-686. [CrossRef]

47. Bonetta, S.; Bonetta, S.; Ferretti, E.; Fezia, G.; Gilli, G.; Carraro, E. Agricultural Reuse of the Digestate from Anaerobic Co-Digestion of Organic Waste: Microbiological Contamination, Metal Hazards and Fertilizing Performance. Water Air Soil Pollut. 2014, 225, 1-11. [CrossRef]

48. Ndubuisi-Nnaji, U.U.; Ofon, U.A.; Ekponne, N.I.; Offiong, N.A.O. Improved biofertilizer properties of digestate from codigestion of brewer's spent grain and palm oil mill effluent by manure supplementation. Sustain. Environ. Res. 2020, 30. [CrossRef]

49. Kabyanga, M.; Balana, B.B.; Mugisha, J.; Walekhwa, P.N.; Smith, J.; Glenk, K. Economic potential of flexible balloon biogas digester among smallholder farmers: A case study from Uganda. Renew. Energy 2018, 120, 392-400. [CrossRef]

50. Shiddiq, A.B.A.; Hermansyah, H.; Wijanarko, A.; Utami, T.S.; Sahlan, M. Analysis for the feasibility of portable biodigester to produce household scale energy. AIP Conf. Proc. 2020, 2255, 030048. [CrossRef] 